\title{
The Influence of Motivation and Self-Efficacy Towards The Students' Entrepreneurship Interest in Muhammadiyah University of Palangkaraya
}

\author{
Endang Sri Suyati ${ }^{*}$, Achmad Zainul Rozikin ${ }^{2}$ \\ 1,2 Universitas Muhammadiyah Palangkaraya, Indonesia \\ 1endangsuyati@yahoo.co.id, 2achmadzainulrozikin@gmail.com, *corresponding author
}

\begin{abstract}
The students' interest in becoming entrepreneurs is influenced by several factors, such as motivation and self-efficacy. This study aimed to determine the effect of motivation and self-efficacy on students' interest in entrepreneurship at the Muhammadiyah University of Palangkaraya. This research is included in causal associative research. There are three variables in this research, they are entrepreneurial motivation, self-efficacy, and interest in entrepreneurship. The data were taken using a questionnaire. The population of this study was 1635 students, while the sample was 327 students. The researchers used a random sampling technique to choose the sample. This study used multiple regression methods. The results of this study indicated that there was an influence between motivation and self-efficacy on entrepreneurial intentions simultaneously or partially. This study indicated that the motivation variable significantly contributed to entrepreneurial interest than the self-efficacy variable.
\end{abstract}

Keywords: motivation, self-efficacy, entrepreneurship interest

\section{Pengaruh Motivasi dan Efikasi Diri Terhadap Minat Berwirausaha Mahasiswa Universitas Muhammadiyah Palangkaraya}

\begin{abstract}
Abstrak
Ketertarikan untuk menjadi wirausahawan pada mahasiswa dipengaruhi oleh beberapa faktor, diantaranya adalah motivasi dan efikasi diri pada mahasiswa itu sendiri. Tujuan penelitian ini adalah untuk mengetahui pengaruh motivasi dan efikasi diri terhadap minat berwirausaha mahasiswa Universitas Muhammadiyah Palangkaraya. Penelitian ini termasuk dalam penelitian asosiatif kausal. Data dari ketiga variabel (motivasi berwirausaha, efikasi diri dan minat berwirausaha) diambil dengan menggunakan angket. Populasi penelitian ini sebanyak 1635 mahasiswa, sedangkan sampelnya berjumlah 327 mahasiswa. Sampel diambil menggunakan teknik random sampling. Penelitian ini menggunakan metode regresi berganda. Hasil penelitian ini menunjukkan bahwa terdapat pengaruh antara motivasi dan efikasi diri terhadap niat berwirausaha secara simultan maupun parsial. Hasil penelitian ini juga menunjukkan bahwa variabel motivasi memiliki kontribusi terhadap minat berwirausaha yang lebih besar daripada variabel efikasi diri.
\end{abstract}

Kata kunci: motivasi, efikasi diri, minat berwirausaha

\section{INTRODUCTION}

Recently, entrepreneurship has become a significant issue at various national and international institutions. This issue has become popular because entrepreneurship has a significant role in a country's economy (Raza, Qazi, \& Shah, 2018), such as opening employment, reducing unemployment, increasing economic growth, and modernizing technology (Baumol, Litan, \& Schramm, 2007). Entrepreneurship is also a modernizer of innovation because it is the knowledge to turn an item into a valuable product, form an organization, and do marketing (Romano, Passiante, Del Vecchio, \& Secundo, 2014). Young people, like students, usually do entrepreneurship. 
Indonesian students are more interested in working in well-known companies and public servants than becoming entrepreneurs (Herdjiono, Puspa, Maulany, \& Aldy, 2017). Entrepreneurship has a high risk, and entrepreneurs are continually experiencing several failures to achieve success. Therefore, entrepreneurship cannot be done by people who have a low psychological. Students who do not want to be entrepreneurs have a low psychological level (Ferreira, Raposo, Rodrigues, Dinis, \& do Paço, 2012). People with the common psychological issue generally tend to be easily discouraged and blame others for the failures. A high psychological level, such as having the motivation to be entrepreneurs, is needed in entrepreneurship.

Basic psychological needs theory (BPNT) is one of the sub-theories of selfdetermination that conceptualizes three psychological needs: autonomy, competence, and relevance, as the essential nutrients for people to perform optimally and grow psychologically (Deci \& Ryan, 2000). The needs are considered a universal thing among the people and the cultures since they apply in all aspects of one's life (Milyavskaya \& Koestner, 2011). The substantial of these needs seems to represent an underlying motivational mechanism that strengthens and guides people's behavior (Deci \& Ryan, 2000).

The students' motivation needs have to be accomplished to enhance the students' interest in entrepreneurship (Malebana, 2014). Motivation consists of two types: internal motivation and external motivation (Locke \& Latham, 2004). Self-determination theory (SDT) distinguishes motivation into several aspects representing a different form of behavior regulation and is assumed to be self-determination (Gagné \& Deci, 2005). At a particular time, intrinsic motivation occurs when someone does a pleasurable activity. Extrinsic motivation occurs when behavior is applied for instrumental reasons (Howard, Gagné, Morin, \& Van den Broeck, 2016). Both of them act as the drivers to change intentions into actions. In this study, motivation has several indicators that were adopted from (Maslow, 1943) namely: actualization needs (developing self-potential, self-creativity, and self-fulfillment) and physiological needs (to stay alive).

Moreover, students' self-efficacy is also needed in enhancing students' interest in entrepreneurship. Someone who wants to be an entrepreneur needs to believe in his abilities. Self-efficacy is a belief in organizing, taking action, and analyzing the situation in achieving the goal as an entrepreneur. Self-efficacy refers to the potential in cognitive and psychological factors, which involves assessing the ability to regulate activity (Zimmerman, 2009). In this study, self-efficacy has several indicators adopted from Utari \& Sukidjo (2020), namely: the confidence of managing business ability, having a leadership spirit of starting a business, and emotional conditions.

The interest of the Muhammadiyah University of Palangkaraya's students in entrepreneurship is still low. It is proved by the results of the interview with 115 students of Muhammadiyah University of Palangkaraya. The results described that there were only 3\% students who want to be entrepreneurs, $18 \%$ want to become teachers, and $7 \%$ want to be lecturers. Moreover, the results of the interview also illustrated some of the students' dream jobs, such as the employees of well-known companies $(28 \%)$, pharmacists $(12 \%)$, civil 
servants (24\%), and undecided (8\%). Therefore, this study examines the effect of motivation and self-efficacy on students' entrepreneurial interest at the University of Muhammadiyah Palangkaraya.

This research has similarities with the previous research conducted by Utari \& Sukidjo (2020). The similarity is to examine students' interest in entrepreneurship. However, the research method, the variables, the research object, and the research subject are different from Utari \& Sukidjo's research. The research conducted by Utari \& Sukidjo (2020) has four variables: the need for achievement, family environment, self-efficacy, and entrepreneurial interest. The research also uses path analysis research methods. The previous research's object is Yogyakarta State University, and the research's subjects are State University students, Yogyakarta.

Moreover, the present study only has three variables: motivation, self-efficacy, and entrepreneurship interest. The present study uses multiple regression analysis methods, and the object of this research is the Muhammadiyah University of Palangkaraya. The research's subjects are the students of the Muhammadiyah University of Palangkaraya. This study also uses two theories: basic psychological needs theory (BPNT) and self-determination theory (SDT). These two theories explain how motivation and self-efficacy affect one's interest in entrepreneurship.

\section{METHOD}

This study used multiple regression analysis that had the variables of self-efficacy, motivation, and interest in entrepreneurship. The dependent variable in this study was entrepreneurial interest, while the independent variable was self-efficacy and motivation. The definition of entrepreneurial interest is the students' desire to establish and own their businesses. Motivation is the students' motivation to own a business and develop the business. Then, self-efficacy is the students' confidence to establish a business.

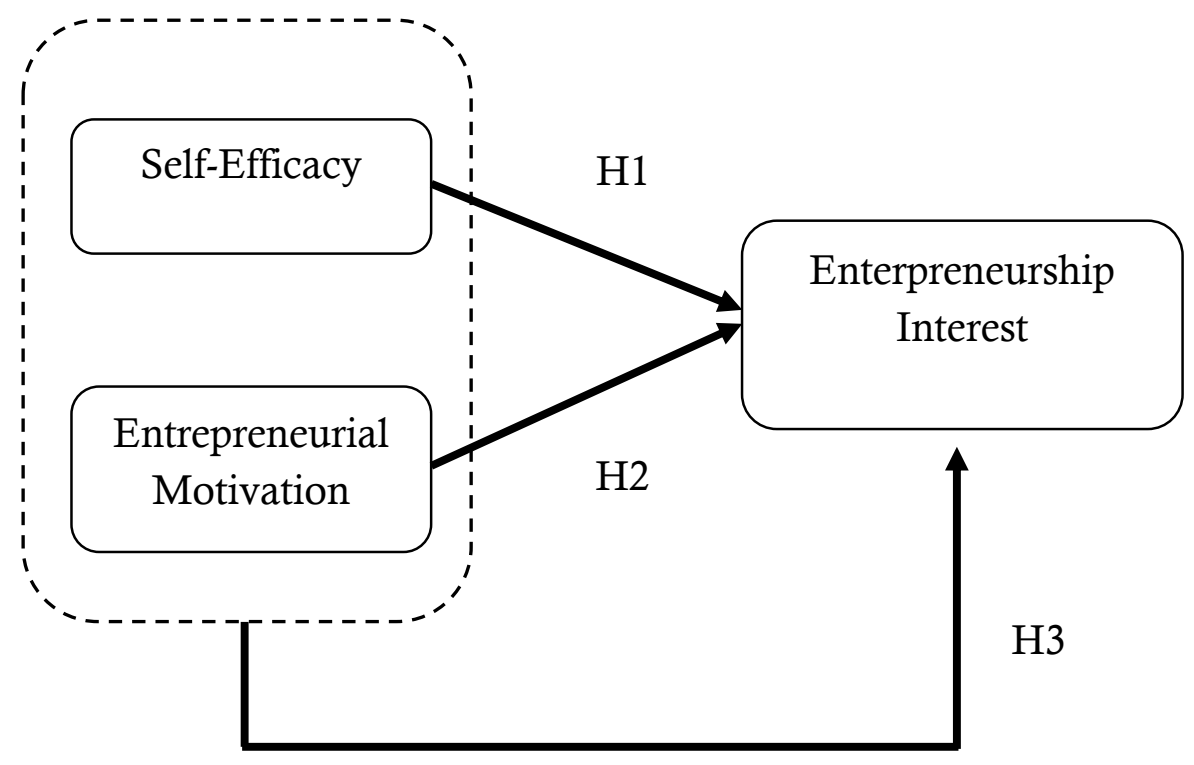

Figure 1. Research Model 
This research was causal associative research because it aimed to determine whether there was a relationship between the dependent and independent variables (Sugiyono, 2013). This research was included in quantitative research. This research instrument adopted previous research and made several developments. The motivation variable's instrument was adapted from Maslow's motivation indicators (1943), and then the researcher developed it independently. The instrument variable of self-efficacy and interest in entrepreneurship was adopted from Utari \& Sukidjo (2020) research. This instrument had 4 Likert scales, namely strongly agree (4 points), agree ( 3 points), disagree ( 2 points), and strongly disagree (1 point). The instrument also contained several negative statements, the value of which was inversely proportional to the positive statement above. This Likert scale applied to all variables in this study (self-efficacy, motivation, and entrepreneurial interest).

Before conducting this research, the research instruments had been tested with validity and reliability tests. In the validity and reliability test, the researcher distributed instruments to 110 respondents consisting of several universities in Indonesia, such as Yogyakarta State University, Lambung Mangkurat University, UIN Antasari Banjarmasin, Muhammadiyah University of Malang, and IAIN Palangkaraya. The validity and reliability tests respondents had the same characteristics as the fundamental research subjects, namely the $4^{\text {th }}$ semester lecturer, and were currently taking an entrepreneurship course. This study had three hypotheses as followed: (1) there is an influence of motivation on the students' interest in entrepreneurship, (2) there is an effect of self-efficacy on the students' interest in entrepreneurship, and (3) there is an influence between motivation and self-efficacy on the students' interest in entrepreneurship.

This study had a total population of 1635 students, with the sample size was 327 students - the current research was taking the samples using a random sampling method with the Slovin formula. Respondents came from all departments in the dictionary, such as majors in economic education, primary school teacher education, pharmacy, health analysts, environmental engineering, civil engineering, computer science, communication science, counseling guidance, and information technology education.

\section{FINDING AND DISCUSSION}

This study was using CFA to test the instruments. According to (Hair, Black, Babin, Anderson, \& Tatham, 2014) an instrument was declared valid if each value is $>0.50$. Whether or not a factor analysis was feasible could be seen using Kaiser Meyer - Olkin (KMO) test. If the index value was high (ranging from 0.5 to 1.0), it described that the factor analysis was feasible. Meanwhile, if the value was below 0.5 , factor analysis could not be carried out (Ghozali, 2013). If the KMO value and Bartlett's Test of Sphericity test described significance, then Anti-Image Correlation value would be seen. If Anti-Image Correlation value of an item was lower than 0.5 , it might be excluded from the factor analysis. Table 1 described KMO and Bartlett's Test of Sphericity test for three variables: entrepreneurial interest, entrepreneurial motivation, and self-efficacy. 
Table 1. KMO test and Bartlett's Test of Sphericity

\begin{tabular}{lcc}
\hline \multicolumn{1}{c}{ Variable } & $\begin{array}{c}\text { Kaiser Meyer - Olkin } \\
(\text { KMO) }\end{array}$ & $\begin{array}{c}\text { Bartlett's Test of } \\
\text { Sphericity (Sig.) }\end{array}$ \\
\hline Entrepreneurial Motivation &, 866 &, 000 \\
Self-Efficacy &, 830 &, 000 \\
Entrepreneurship Interest &, 908 &, 000 \\
\hline
\end{tabular}

Table 1 described that Kaiser Meyer - Olkin (KMO) value of the entrepreneurial motivation variable was 0.886 , and the significance value was 0.000 . Anti-image matrix correlation (attachment) table indicated that 19 items had item values above 0.5. Based on the total variance explained, from 19 items analyzed resulted in 3 factors. There were 19 invalid items and 1 item was invalid. So, it could be concluded that the remaining of 18 statement items were suitable for research and could be analyzed further. In contrast, 1 item was not used in the study.

Table 1 presented that Kaiser Meyer - Olkin (KMO) value of the self-efficacy variable was 0.830 , and a significance value was 0.000 . Anti-image matrix correlation (attachment) table presented that 14 items had item values above 0.5 . Based on the total variance explained, from the 14 items analyzed, three factors were generated. There were 14 invalid items and 2 items were invalid. So, it could be concluded that the remaining of 12 statement items were suitable for research and could be analyzed further. Meanwhile, these two items were not used in the study.

Table 1 presented that Kaiser Meyer - Olkin (KMO) value of the entrepreneurial interest variable was 0.908 , and the significance value was 0.000 . Anti-image matrix correlation (attachment) table presented that 11 items had item values above 0.5 . Based on the total variance explained, there were 11 items analyzed resulted in 4 factors. From 11 items, there was only one invalid item. So, it could be concluded that the remaining of 10 statement items were suitable for research and could be analyzed further, whereas 1 item was not used in the study.

After doing validity test, the next step was reliability test. Reliability test of this study could be described in the table below:

Table 2. Reliability Test

\begin{tabular}{lccc}
\hline \multicolumn{1}{c}{ Variable } & $\begin{array}{c}\text { Normal } \\
\text { Limit }\end{array}$ & $\begin{array}{c}\text { Nilai Cronbach's } \\
\text { Alpha }\end{array}$ & Information \\
\hline Entrepreneurial Motivation & 0,70 & 0,903 & Reliable \\
Self-Efficacy & 0,70 & 0,846 & Reliable \\
Entrepreneurship Interest & 0,70 & 0,920 & Reliable \\
\hline
\end{tabular}

Table 2 described that all statement items of the variables studied were reliable because they had a Cronbach's Alpha value $>0.70$. So, it could be concluded that the instruments of entrepreneurial motivation, self-efficacy, and interest in entrepreneurship were reliable.

Based on table 3, this study also used a classic assumption test before conducting multiple regression tests. A normality test, linearity test, multicollinearity test, and 
heteroscedasticity test were classic assumption tests. The normality test of this study had a significant value of 0.741 . Linearity test had a Deviation from Linearity (DfL) value divided into two, namely the variables of entrepreneurial motivation and self-efficacy. DfL of entrepreneurial motivation was 0.999 , while DfL of self-efficacy was 0.347 .

Table 3. Classic assumption test

\begin{tabular}{lccccc}
\hline & Normality & Linearity & Multicollinearity & Heteroscedasticity \\
\cline { 2 - 6 } Variable & Sig. & $\begin{array}{c}\text { Deviation } \\
\text { from } \\
\text { Linearity }\end{array}$ & Tolerance & VIF & Sig. \\
\hline $\begin{array}{l}\text { Entrepreneurial } \\
\text { Motivation } \\
\text { Self-Efficacy }\end{array}$ &, 741 &, 999 &, 545 & 1,834 &, 887 \\
\hline
\end{tabular}

Multicollinearity tests could be seen from the Tolerance and VIF columns. Tolerance and VIF on entrepreneurial motivation and self-efficacy variables had the same values; they were 0.545 (Tolerance) and 1.834 (VIF). The Htereoscedasticity test in the study had a different significance. The entrepreneurial motivation variable had a significant value of 0.887 , while the significant value of self-efficacy was 0.079 .

After testing the instrument's validity and reliability and testing the classical assumptions, the next step was to test the hypothesis.

Table 4. Multiple Regression

\begin{tabular}{|c|c|c|c|c|c|c|}
\hline \multirow{2}{*}{\multicolumn{2}{|c|}{ Model }} & \multicolumn{2}{|c|}{$\begin{array}{l}\text { Unstandardized } \\
\text { Coefficients }\end{array}$} & \multirow{2}{*}{$\begin{array}{c}\text { Standardized } \\
\text { Coefficients }\end{array}$} & \multirow[t]{2}{*}{$\mathrm{t}$} & \multirow[t]{2}{*}{ Sig. } \\
\hline & & B & Std. Error & & & \\
\hline \multirow{3}{*}{1} & (Constant) &,- 002 & 1,774 & &,- 001 & ,999 \\
\hline & $\begin{array}{l}\text { Self-Efficacy } \\
\text { (X1) }\end{array}$ & 221 & ,053 & 215 & 4,175 & 000 \\
\hline & $\begin{array}{l}\text { Entrepreneurial } \\
\text { Motivation } \\
\text { (X2) }\end{array}$ & ,417 & ,038 & ,565 & 10,958 & ,000 \\
\hline
\end{tabular}

Dependent Variable: Entrepreneurship Interest (Y)

Based on table 4, the value of self-efficacy and entrepreneurial motivation variables had the same significance value of 0,000 . The coefficient or contribution (Adjusted R Square $\left.=\mathrm{R}_{\mathrm{X} 1 \mathrm{X} 2 \mathrm{Y}}^{2}\right)=0.527$. Thus, the magnitude of the residual coefficient $\rho \mathrm{Y} \varepsilon=\sqrt{1-0,527}=$ 0.69 . Therefore, it could be concluded that the contribution of entrepreneurial motivation and self-efficacy to entrepreneurship interests simultaneously amounted to $69 \%$, while $31 \%$ was influenced by other variables not examined. For partial contributions, self-efficacy contributed $21.5 \%$, while entrepreneurship motivation contributed $56.5 \%$. 
Based on the calculation of the results above, it could be described as a whole that illustrated the empirical causal relationship between variable $\mathrm{X}$ to variable Y (Figure 2).

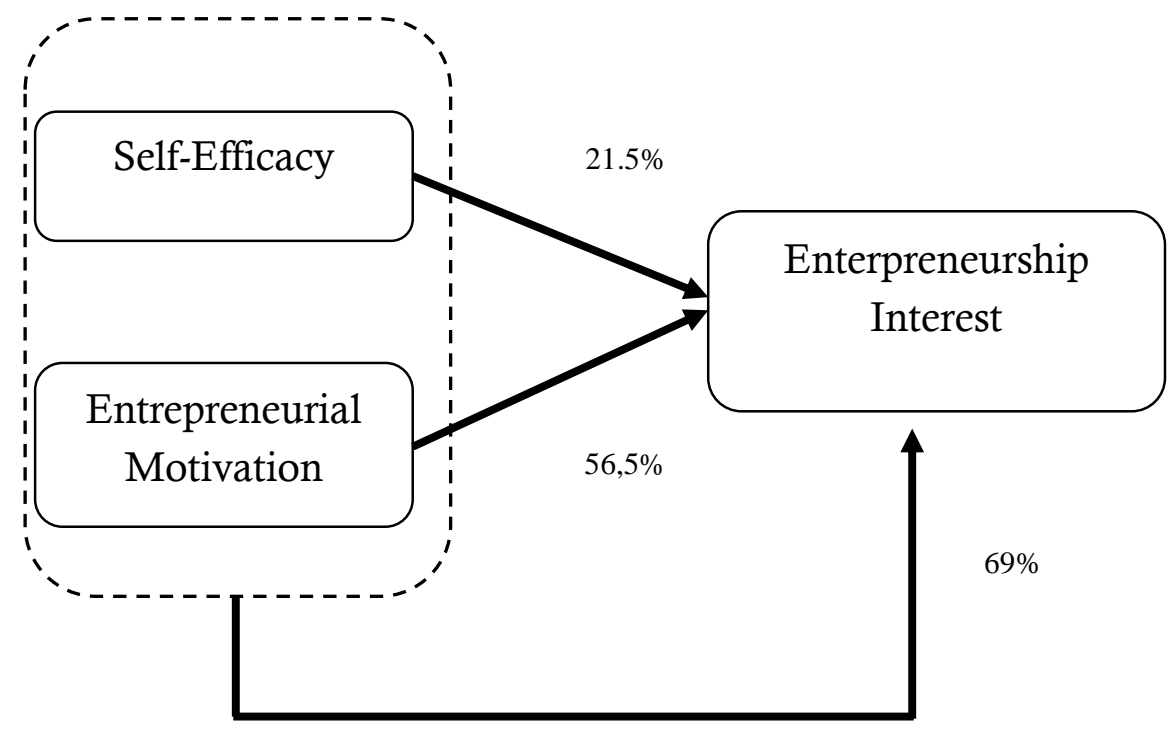

Figure 2. The Result of Research

These results indicated that entrepreneurial motivation had a more significant contribution than self-efficacy. This statement was following by self-determination theory (SDT). Based on SDT theory, motivation was assumed as a determinant of one's destiny (Gagné \& Deci, 2005). Intrinsic motivation occurred when someone performed pleasurable activities. In contrast, extrinsic motivation was instrumental because individual actions were carried out within the control of parties outside the individual self (Howard et al., 2016).

Someone did the activity depending on the motivation. Following Rozikin \& Sugiharsono's (2019) statement, a person's activities were influenced by high or low motivation. Therefore, motivation had a vital role in determining one's activities (Azzahra $\&$ Dhewanto, 2015). Actions that arise because of motivation would produce a productive activity. The motivation was also a psychological urge from within a person to take action (Azmi, 2017). Besides psychology, motivation was influenced by one's self-efficacy (Bandura, 2012).

Self-efficacy was one of the most influential aspects of knowledge about oneself in daily life (Sartika \& Sugiharsono, 2020). Self-efficacy affected the individual in determining the actions to achieve a goal, including estimating various events that would be faced.

Self-efficacy was related to one's self-esteem to affect one's success or failure (Sartika $\&$ Sugiharsono, 2020). Someone who had high self-efficacy and high motivation would make that person do activities. Conversely, if someone had low self-efficacy and low motivation, they would not desire to do an activity. This statement was under the opinion of Bandura (2012), who emphasizes that self-efficacy influenced the consideration of something seriously in the decision-making process for a career. This self-efficacy also affected the decision-making for entrepreneurship which was called entrepreneurial selfefficacy. 
Previous research conducted by Boyd \& Vozikis, 1994; Chen, Greene, \& Crick, 1998; Pihie \& Bagheri, 2013; and Trevelyan, 2011 presented that self-efficacy influenced one's intention to entrepreneurship. As proof, the people created a new business, persistent in dealing with various challenges of creating new businesses, and successfully carrying out entrepreneurial roles and tasks. Self-efficacy was the key to entrepreneurial behavior motivation (Tyszka, Cieślik, Domurat, \& Macko, 2011) and a person's motivation to overcome problems or difficulties during the entrepreneurship process (Tumasjan \& Braun, 2012). Therefore, entrepreneurial self-efficacy affected an individual's decision to entrepreneurship and affected his performance in managing and developing a business (McGee, Peterson, Mueller, \& Sequeira, 2009).

\section{CONCLUSION}

Based on the explanation above, it can be concluded that entrepreneurial motivation and entrepreneurial self-efficacy can affect student entrepreneurial interest. One of the factors is the students have to be interested in being entrepreneurs because of a need. The need is one part of the instrumental motivation. Students' need factor alone is not enough to enhance student entrepreneurship motivation, but it also requires encouragement from the campus or educators to grow it.

Enhance the motivation for entrepreneurship can be done through entrepreneurship education. In entrepreneurship education, educators need to utilize educational activities to develop self-efficacy. Self-efficacy development can improve student self-regulation by emphasizing more challenging and experimental learning methods and emphasizing successful goals. Therefore, entrepreneurial educators need to be trained and equipped with skills to design and implement various pedagogical methods to enhance entrepreneurial selfefficacy and entrepreneurial motivation.

\section{ACKNOWLEDGEMENT}

Sincerely, thanks to the Chancellor of the University of Muhammadiyah Palangkaraya for funding this research. Also, thanks to colleagues who have provided constructive encouragement and criticism. So, this article can be completed correctly and on time.

\section{REFERENCES}

Azmi, I. A. G. (2017). Muslim women entrepreneurs motivation in SMEs: a quantitative study in Asia pacific countries. Asian Economic and Financial Review, 7(1), 27. https://doi.org/10.18488/JOURNAL.AEFR\%2F2017.7.1\%2F102.1.27.42.

Azzahra, S., \& Dhewanto, W. (2015). Entrepreneurship training for community in rural area: Motivation and knowledge of entrepreneurship. Advanced Science Letters, 21(6), 1858-1862. https://doi.org/10.1166/as1.2015.6137.

Bandura, A. (2012). On the functional properties of perceived self-efficacy revisited. Sage Publications Sage CA: Los Angeles, CA. https://doi.org/10.1177\%2F0149206311410606. 
Baumol, W. J., Litan, R. E., \& Schramm, C. J. (2007). Sustaining entrepreneurial capitalism. Capitalism and Society, 2(2). https://doi.org/10.2202/1932-0213.1026.

Deci, E. L., \& Ryan, R. M. (2000). The" what" and" why" of goal pursuits: Human needs and the self-determination of behavior. Psychological Inquiry, 11(4), 227-268. https://doi.org/10.1207/S15327965PLI1104_01.

Ferreira, J. J., Raposo, M. L., Rodrigues, R. G., Dinis, A., \& do Paço, A. (2012). A model of entrepreneurial intention: An application of the psychological and behavioral approaches. Journal of Small Business and Enterprise Development. https://doi.org/10.1108/14626001211250144.

Gagné, M., \& Deci, E. L. (2005). Self-determination theory and work motivation. Journal of Organizational Behavior, 26(4), 331-362. https://doi.org/10.1002/job.322.

Ghozali, I. (2013). Aplikasi Analisis Multivariate dengan Program IBM SPSS (Edisi Ketujuh). Semarang: Badan Penerbit Universitas Diponegoro.

Hair, J. F., Black, W. C., Babin, B. J., Anderson, R. E., \& Tatham, R. L. (2014). Pearson new international edition. In Multivariate data analysis, Seventh Edition. Pearson Education Limited Harlow, Essex.

Herdjiono, I., Puspa, Y. H., Maulany, G., \& Aldy, B. E. (2017). The factors affecting entrepreneurship intention. International Journal of Entrepreneurial Knowledge, 5(2), 5-15. http://dspace.vsp.cz/handle/ijek/69.

Howard, J., Gagné, M., Morin, A. J. S., \& Van den Broeck, A. (2016). Motivation profiles at work: A self-determination theory approach. Journal of Vocational Behavior, 95, 7489. https://doi.org/10.1016/j.jvb.2016.07.004.

Locke, E. A., \& Latham, G. P. (2004). What should we do about motivation theory? Six recommendations for the twenty-first century. Academy of Management Review, 29(3), 388-403. https://doi.org/10.5465/amr.2004.13670974.

Malebana, M. J. (2014). Entrepreneurial intentions and entrepreneurial motivation of South African rural university students. Journal of Economics and Behavioral Studies, 6(9), 709726. https://doi.org/10.22610/jebs.v6i9.531.

Maslow, A. H. (1943). A theory of human motivation. Psychological Review, 50(4), 370. https://psycnet.apa.org/doi/10.1037/h0054346.

McGee, J. E., Peterson, M., Mueller, S. L., \& Sequeira, J. M. (2009). Entrepreneurial selfefficacy: Refining the measure. Entrepreneurship Theory and Practice, 33(4), 965-988. https://doi.org/10.1111\%2Fj.1540-6520.2009.00304.X.

Milyavskaya, M., \& Koestner, R. (2011). Psychological needs, motivation, and well-being: A test of self-determination theory across multiple domains. Personality and Individual Differences, 50(3), 387-391. https://doi.org/10.1016/j.paid.2010.10.029.

Raza, S. A., Qazi, W., \& Shah, N. (2018). Factors affecting the motivation and intention to become an entrepreneur among business university students. International Journal of Knowledge and Learning, 12(3), 221-241. https://doi.org/10.1504/IJKL.2018.092315. 
Romano, A., Passiante, G., Del Vecchio, P., \& Secundo, G. (2014). The innovation ecosystem as booster for the innovative entrepreneurship in the smart specialisation strategy. International Journal of Knowledge-Based Development, 5(3), 271-288. https://doi.org/10.1504/IJKBD.2014.065315.

Sartika, N. Y., \& Sugiharsono, S. (2020). Self-Efficacy and Intensity of the Use of Social Media on Consumption Behavior: Case Study in the Economics Faculty of Yogyakarta State University. Jurnal Economia, 16(1), 71-85. https://journal.uny.ac.id/index.php/economia/article/view/27067.

Sugiyono. (2013). Metode penelitian pendekatan kualitatif, kuantitatif, dan $R \& D$. Bandung: CV. Alfabeta.

Tumasjan, A., \& Braun, R. (2012). In the eye of the beholder: How regulatory focus and self-efficacy interact in influencing opportunity recognition. Journal of Business Venturing, 27(6), 622-636. https://doi.org/10.1016/j.jbusvent.2011.08.001.

Tyszka, T., Cieślik, J., Domurat, A., \& Macko, A. (2011). Motivation, self-efficacy, and risk attitudes among entrepreneurs during transition to a market economy. The Journal of Socio-Economics, 40(2), 124-131. https://doi.org/10.1016/j.socec.2011.01.011.

Utari, F. D., \& Sukidjo, S. (2020). The Roles of Need for Achievement and Family Environment in Stimulating Entrepreneurial Interest through Self-Efficacy. Jurnal Economia, $16(2)$ 143-160. https://journal.uny.ac.id/index.php/economia/article/view/28725.

Zimmerman, B. (2009). Self-Efficacy and Educational Development: Self-Efficacy in Changing Societies. New York: W.H. Freeman and Company. 